\title{
Autosomal recessive spastic paraplegia type 18
}

INSERM

\section{Source}

INSERM. (1999). Orphanet: an online rare disease and orphan drug data base. Autosomal recessive spastic paraplegia type 18. ORPHA:209951

Autosomal recessive spastic paraplegia type 18 (SPG18) is a rare, complex type of hereditary spastic paraplegia characterized by progressive spastic paraplegia (presenting in early childhood) associated with delayed motor development, severe intellectual disability and joint contractures. A thin corpus callosum is equally noted on brain magnetic resonance imaging. SPG18 is caused by a mutation in the ERLIN2 gene (8p11.2) encoding the protein, Erlin-2. 